Committee in the form of grants for approved work. The Committee propose, initially, to support, co-ordinate and publish work undertaken throughout the Country.

Yours faithfully,

Colonel P. T. ETHERTON,

Secretary.

ROYAL EYE HOSPITAL,

LONDON, S.E.1.

April 19, 1945.

\title{
OBITUARY
}

\section{DAVID LEIGHTON DAVIES}

THE death took place at Llandrindod Wells, on April 6, of David Leighton Davies, M.D., M.S., F.R.C.S.; Honorary Consulting Ophthalmic Surgeon to the Cardiff Royal Infirmary.

$\mathrm{He}$ was educated. at Christ College, Brecon, and University College, London. He became qualified in 1900 ; took his M:D., of London University in 1902, the M.S., in 1904 and the F.R.C.S. (England) in 1909.

After a period as Clinical Assistant in University College Hospital, he came to Cardiff where he was appointed Honorary Assistant Ophthalmic Surgeon to the Cardiff Royal Infirmary in 1910, was elevated to the Senior Staff in 1920 and remained an active member - of the Honorary Staff until 1937.

From 1941 he lived in semi-retirement in Llandrindod Wells and in June last year developed acute heart trouble from which he recovered to some extent, but succumbed to another attack on April 6. The burial took place in Llangeitho Churchyard.

For many years during the early part of his time in Cardiff he held the post of Lecturer and Demonstrator in Anatomy at the Medical School, and old students of the school will remember how well fitted he was for the post. He was a good teacher, careful and painstaking in his work, with a clear and concise method of expression that made him both popular and respected by the students. He held the office of Consulting Ophthalmic Surgeon to the Welsh National Memorial Association for Tuberculosis, and was a Medical Referee for Ophthalmic Cases.

For many years he was Lecturer in Ophthalmology in the Welsh National School of Medicine and had been an examiner for the Diploma of Ophthalmic Medicine and Surgery in London.

He was a member of the Ophthalmological Society of the United Kingdom: a Fellow of the Royal Society of Medicine and a member and Ex-President of the South Western Ophthalmological Society. $\mathrm{He}$ regularly attended the Oxford Ophthalmological Congress and made various contributions to ophthalmic literature, taking a keen interest in dacryo-rhinostomy as a means of treatment for lacrymal sac obstruction. 
As an opl talmologist he was careful and thorough, preserving a wide outlook in his clinical work.

Leighton Davies was a modest man of retiring disposition and preferred -a family life to wider social activities. His duties were carried out faithfully and well, and he maintained a high standard of ophthalmological work. He was a man of high moral principles and stern character, and took great interest in Church affairs, and was a member of the Representative Body and the Governing Body of the Church in Wales. He is survived by his widow and two daughters.

By the passing of David Leighton Davies-familiarly known to Students and Staff. as "Leighton," Cardiff has lost a distinguished and highly respected man, who had earned a deserved reputation in his speciality, and his loss will be deeply regretted by numerous friends and colleagues in Cardiff and South Wales and in ophthalmological circles throughout the Country.

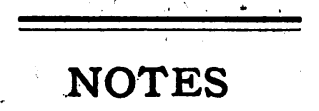

Deaths THE deaths of the following well-known American ophthalmologists have been announced: Mark J. Schoenberg of New York City and Ellice M. Alger, also of New York City. Dr. Schoenberg was born in Roumania in 1874 and went to the States in 1900 after having graduated at Bucharest. He wrote much on glaucoma and was consulting surgeon to the Manhattan Eye, Ear and Throat Hospital as well as consultant ophthalmologist at the Bronx Hospital and attending surgeon at the Herman Knapp Memorial Hospital for twenty-three years. Schoenberg was chairman of the committee on glaucoma of the National Society on the Prevention of Blindness and a member of the editorial staff of the Sight-saving Review.

Dr. Alger was born in 1870 and graduated from Vermont in 1890. Three years later he went to New York. He had been a founder of the National Society for the Prevention of Blindnees and served on its Board of Directors. He received the Leslie Dana Gold Medal in 1938. For more than a quarter of a century he was Professor of Ophthalmology in New York Post-graduate Medical School.

Honours THE Hon. Fellowship of the Australian Ophthalmological Society has been conferred upon Sir John Parsons, F.R.S.

Lieut.Col. B. W. Rycroft, R.A.M.C. has been awarded the O.B.E.

Special Notice

WE are asked by the Ministry of Information to state that the fact that goods made of raw materials in short supply owing to war conditions are advertised in this journal should not be taken as an-indication that they are necessarily available for export. 